\title{
CrossRefを介した学術文献リンキング
}

\author{
BRAND, Amy ${ }^{1}$ : 著 \\ 高木和子 ${ }^{2}$ : 訳
}

\begin{abstract}
著者抄録 :CrossRefは, 共有技術を築くことを目的とした自立的な会員制の協会である。その使命は 学術出版社や専門書出版社間での共通な合意が求められるサービスを通して, 学問研究の出版物へ のアクセスを向上させることである。CrossRefのネットワークは今日, 数百の出版社から出版され る数百万の論文やその他コンテンツを網羅する。本記事は, CrossRefが2000年に開始されて以来ど こまで進んだか, そして科学・学術・専門コンテンツをオンラインでリンクする真に包括的なネッ トワークに到達するには, 何を進める必要があるかを見ていく。

キーワード : CrossRef, リンク, OpenURL, ドキュメントオブジェクトアイデンティファイア, オ ンライン, 学術資料, 出版社, 電子ジャーナル
\end{abstract}

\section{Linking scholarly literature through CrossRef}

\author{
written by BRAND, Amy ${ }^{1}$ \\ translated by TAKAGI Kazuko²
}

\begin{abstract}
Author Abstract: CrossRef is an independent membership association for building shared technologies. Its mission: to enhance is to improve access to published scholarship through services that require collective agreement among scholarly and professional publishers. The CrossRef network today covers millions of articles and other content items from several hundred publishers. This article looks at how far CrossRef has come since it launched in 2000, and what needs to happen going forward in order to arrive at a truly comprehensive linking network for scientific, scholarly, and professional content online.
\end{abstract}

Key words: CrossRef, link, OpenURL, DOI, online, scholarly resources, publisher, electronic journal

\section{1. はじめに}

CrossRefは，共有技術を築くことを目的とした 自立的な会員制の協会である。その使命は学術出 版社や専門書出版社間での共通した合意が求めら れるサービスを通して, 学問研究の出版物へのア クセスを向上させることである。CrossRefはその 出版社間の横断レファレンス・リンキング・サー ビスを開始してからこの4年のうちに, 財政的に独 立採算を実現し, 情報産業のさまざまな部門の注 目に值する財政目標値に達した。当論文では,
CrossRefの現状と, CrossRefが2000年に開始されて 以来どこまで仕事を進めてきたか, そして科学. 学術・専門コンテンツをオンラインでリンクする 真に包括的なネットワークに到達するには, 今後 何を進める必要があるかについて概説する。

\section{2. 背景}

CrossRefは2000年の初めに, デジタル・オブジェ クト識別子 (Digital Object Identifier, DOI) を利用し て, ジャーナル中の引用文献のリンク付けを可能

12001年4月にビジネス開発部長としてCrossRefに加わった。電子出版, 図書出版, 学究と多岐にわたる経歴を有する。 1989年に認知科学の博士号をMITから取得, CrossRefに加わる以前は, Ingenta, MIT Press, Lawrence Erlbaum

Associates, Pennsylvania大学に勤務した。CrossRef/PILA（E-mail: abrand@crossref.org）

${ }^{1}$ Director of Business Development, CrossRef/PILA (40 Salem Street, Lynnfield, MA 01940, USA)

2科学技術振興機構「情報管理」編集事務局気付（†102-8666 東京都千代田区四番町5-3）

${ }^{2}$ c/oJOHO KANRI Editorial Office, Japan Science and Technology Agency (5-3, Yonban-cho, Tokyo, 102-8666) 
にするための出版社間の協働的取り組みとして始 まった。DOIは図書, ジャーナル論文, 章, 画像な どのデジタルコンテンツに付与される英数字名(例 えば, “doi:10.1101/gr.10.12.1841” ) である。DOIの 体系はNISO 規格（http://www.niso.org/ (accessed 2004-07-29)）である（DOI-Xプロジェクトでの CrossRef のルーツの詳細は, Atkins らの論文” Reference Linking with DOIs.” D-Lib Magazine. Vol.6, No.2, 2000, http://www.dlib.org/dlib/february00/ 02risher.html (accessed 2004-07-29) )。

DOIは, オブジェクトの電子アドレス, もしくは URLとの対としてDOIディレクトリに記載される。 このダイレクトリの更新は容易である。DOIはリ ンクに欠落がないようURLに代わって使われるが, そのコンテンツ自体は必要に応じて移動できる。 例えば，出版社はコンテンツをひとつの制作シス テムから他の制作システム（プレプリントからポ ストプリント）へと移動する必要があるであろう し, ジャーナルまたは出版社の所有者が変われば, そのコンテンツ自体はある出版社から別の出版社 へと移動することもある。こういった場合, DOIは 決して変わらない。つまりすでに出版され流通さ れているコンテンツにすでに張ってあるハイパー リンクは, 出版社等が変わってもその機能は依然 として保たれるのである。それゆえ, DOIシステム のひとつのキーとなる点は持続性である。そして キーとなる別の点は作動性である。それはURLの ようなもので, DOIを1回クリックすれば望みのコ ンテンツの場所に利用者を導けなければならない。

CrossRefは，国際DOI財団（International DOI Foundation) (http://www.doi.org (accessed 2004-0729)）が指名する正式のDOI登録機関である。今日 に至るまでCrossRefはDOIモデルの最も活発な施行 機関である。CrossRefは, 当初STM分野のジャーナ ル論文のリンクに特に焦点を当てていたが, 現在 はDOIをべースとする学術・専門文献のリンク付 けをカバーしており，その中には多様なコンテン ツタイプや専門分野が含まれる。CrossRef会員を Webサイト (http://www.crossref.org/01company/ 06publishers.html (accessed 2004-07-29)) 上で見ると， CrossRefがどれほど多岐の専門分野にわたり，国 際的であるかがわかる。

\section{CrossRefはどのように作動するのか}

参加出版社は自動化処理により, メタデータ・
レコードをCrossRefのメタデータ・データベース にデポジットする。デポジットされるレコードは 最小限の書誌情報, DOI, およびそのコンテンツが 見られる出版社などのURLである。ジャーナル論 文の場合は，記述メタデータを意味し，すなわち ジャーナル誌名, ISSN, 第一著者名, 年, 巻, 号, ページ番号を含む。メタデータ・レコードがデポ ジットされた後,CrossRefはDOI-URL対を中央ディ レクトリに登録する。利用者がDOIをクリックす ると，この中央DOIディレクトリを経由して対と なっているURLを探し, そのURLのコンテンツが 利用者のPC画面に表示される。

出版社はレコードをデポジットすると，即座に 出版社のそのコンテンツが掲載してあるWebペー ジにリンクできるよう設定する。出版社や図書館 員, 仲介業者がCrossRefからDOIを検索するプロセ スは自動化されている。このプロセスでは, DOIを 検䒺する機関はジャーナルの参考文献，もしくは 書誌レコードをレファレンスリゾルバに提出する。 このレファレンスリゾルバはC CrossRefデータベー スの中で, これらのレコードが合致するか否かを 探し，合致するものが見つかると該当するDOIを 返す。返されたDOIを使えば出版社は, CrossRefシ ステムに登録済みアイテムの引用文献やレコード に持続的な外部ハイパーリンクを加えることがで きる。レファレンス・リゾルバーはDOIをインプッ トとして受け取り, メタデータをアウトプットと して送り返すこともできる。図1は参考文献・リン キングのための, 出版社のワークフローの概観を 示す。

メタデータとDOIがCrossRefにデポジットされる と, 出版社は八ってくるリンクを論文レベルで受 けつけられるようレスポンスページをWeb上で掲 載していなくてはならない。そのページは最小限, フル書誌情報とフルテキストへのアクセスができ るような手段で構成される。フルテキストアクセ スのビジネスモデルは出版社の管轄下にある。 CrossRef自身はアクセスモデルを中立に保つ。ほ とんどの出版社はデフォルトとして利用者を抄録 ページにアクセスさせ, 認定ユーザには直接フル テキストにアクセスするようにする。ただしフル テキストが無料の場合は，すべての利用者は即座 にそのフルテキストを見ることができる。そして 有料の場合, 出版社の多くは非購読者に対して論 文1部売り（pay-per-view）も用意している。 


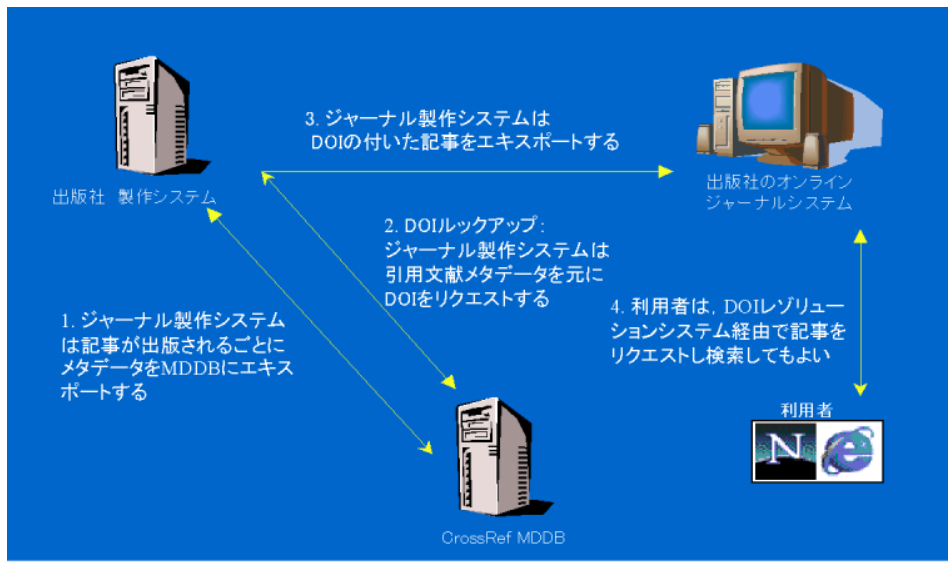

\section{crossef}

図1 参考文献リンク付けのワークフロー

\section{CrossRef の現在}

2004年6月現在,CrossRefは315の出版社メンバー, ジャーナルを1万誌近く, 1,150万のDOIを擁してい る。これに数十万もの雑誌以外のコンテンツのDOI が含まれる。雑誌以外のコンテンツとは, 例えば 図書, 会議の議事録などである。CrossRefシステム は, 年に 200 万から 300 万の新規DOIレコードを追加 する。これらのDOIの多くはバックファイルコン テンツのものである。というのも出版社は過去の 印刷体のみのジャーナルをもデジタル化を進めて いるからである。印刷体の最初の巻までさかのぼ る電子化もある。さらにDOIが増加する別の理由 は, 新規にコンテンツのジャンルが増えているこ とである。ジャーナルコンテンツを相当の期間登 録してきた出版社は, 今や別のタイプのコンテン ツにもDOIを登録するに至っており, ジャーナル を出版していない新規会員は図書や会議録を登録 するようになってきている。

CrossRefは, 会員がさまざまなレべルでますま す広がるコンテンツタイプにDOIを付与していく という根拠に立って, 仕事を進めている。新しい コンテンツタイプやコンポーネントを受け入れる ために, CrossRefは新しいシステム能力を築き上 げ, 画像, 百科事典の記載事項, データ類, 定理 といった多様なコンテンツタイプに会員がDOIを 付与することができるように, 適切な料金や方針 を確立する準備を行っている。

今日のCrossRefの成功は, 文献リサーチという 体験に与えるインパクトの媣さで最も良く測れる。 DOIは現在, 月に約500万から600万回, クリックさ
れ論文にリンクされている。おおざっぱに言って 月に 200 万のDOIがシステムから検索されている。 つまり, DOIベースのリンクがこの数だけあるこ とがわかる。会員として参加している300以上の出 版社に加えて, 眓書館, データベース出版社, フ ルテキスト・アグリゲータ,ソフトウエアベンダー, ジャーナル・ホスト/リンキング・プラットフォー ムなど, 300 を越える機関が参加している。これら の仲介業者は, 定期的にCrossRefのDOIデータベー スやメタデータを問い合わせてその仲介業者が扱 う製品からリンクを張るのである。次の章では, 情報分野のさまざまなコミュニティに及ぼす CrossRefのインパクトを見ていく。

\section{CrossRefのインパクト}

Association of Learned and Professional Society Publishersの事務局長 Sally Morrisは,「学術ジャー ナルの大多数は今やオンラインであり, 研究者が 電子ジャーナルのどの特性を最も価值あると見る かに関する数多くの研究がされてきている。引用 文献, 引用された原著論文, そして書誌データベー スとのシームレスなリンクは常に極めて高い評価 を受けている。DOIとCrossRefは機能性の高い, 持 続的なリンクで, オンライン学術文献を充実させ るという柔軟さを増す方法を提供する」と述べる。 (私信)

\section{(1) 出版社に及ぼすインパクト}

出版社間の横断的リンク付けは出版社にいくつ かの利点をもたらす。1番目のそして最も重要な利 
点は, 出版社のWebサイトや, その出版社の出版 物にその利用者を導くことである。利用者を外部 の資料や場所いずれからであってもコンテンツに 接続させることにより，ドキュメントデリバリー サービスであっても, 仲介業者を介したとしても， または論文1部売りのメカニズムを使うにしても購 読資料だけでなく，記事単位もしくは章単位の資 料販売の機会をもたらす。

CrossRefは，持続性のあるリンク付けのための 技術とビジネスインフラストラクチュアを出版社 に提供する。ビジネスサイドでは, 出版社（もし くはその他の利害関係者）は, CrossRefと一対一の 協定に署名すると, 他の全参加出版社へのリンク を張れる権利を得る。さもなければ, 現在 300 以上 の出版社が会員であるので, 上記のリンク接続の ネットワークを作動するには，およそ 5 万もの CrossRefと機関との二者間協定が必要となろう。し たがって,CrossRefのような組織的なインフラス トラクチャアがなければ，この規模でのリンキン グネットワークは実現しないことになる。特に現 在CrossRefの一員である小規模出版社は, 二社間 でのアプローチだけで広範囲な相互リンキングに 参加できる手段や機会を持ちえなかったであろう。

技術サイドでは，上記で述べたようにCrossRef はDOIを利用することで,URLリンクが途切れてし まうという問題を未然に防ぐ。CrossRefデータベー スにコンテンツを登録した出版社は,つまり600を 越える参加機関 (出版社, 抄録・索引データベー ス,アグリゲータ, 図書館）のレスポンスページ に自動的にリンクできることを意味する。参考図 書といった電子図書の場合, CrossRefはその図書 内での章や節, 参考文献へのいわゆる内部リンク もできる。DOIを図書の中の章に付与することか ら, 本来の図書の構成の再配列やその一部を必要 とする派生的な著作コンテンツの組み立てが容易 になる。こういった事態は，例えば，授業の教材 であるとか章レベルでのe-コマースで見られる。出 版社はまた, 進行中の共有技術の開発のための共 同プラットフォームの一部なので, 出版社が単独 で行う開発より利点を得られる。一方で, その出 版社のビジネス実践のコントロールも維持でき, 出版社のコンテンツへのアクセス方法も維持でき る。

小規模出版社にとっては,グローバルな相互リン キングネットワークに参加できるので, 最も直接的 な利益が期待できる。チェコ科学アカデミーが発行 する学際的な化学誌, Collection of Czechoslovak
Chemical Communications の編集マネージャーの Bohumir Valterは次のように語る。CCrossRefに参加 して 2 年後, わがジャーナルのWebサイトへのアク セス量は著しい増加を見たが, これは当ジャーナ ルに発表された論文記事がCrossRefの参考文献リ ンキング・サービスのおかげで, 以前よりずっと アクセスされやすくなったからである。CrossRef はオンライン利用者に偉大なサービスを提供して おり, 利用者はその結果, 急速に数が増大してい る引用論文記事やリンクを張られた論文記事に即 座にアクセスすることができる。私は当ジャーナ ルがCrossRefコミュニティの一員であることを非 常に誇りに思っており, まさしく小規模出版社に とって有益であると考える」。(私信)

\section{(2) 図書館での利用-OpenURLとの統合}

CrossRefシステムは図書館に対して無料で提供 される。現在までに340の図書館とコンソーシアム が登録しており, 毎月, 数機関が契約している（最 新リストはhttp://www.crossref.org/01company/ 07libraries.htmlを参照)。ドイツに本社を置く多国 籍企業Bayer Groupの図書館を含め, 図書館数館は CrossRefからすでに数百万のDOIを検索している。 CrossRef参加図書館の大多数は, CrossRefを利用し て,それぞれのローカルリンクサーバのパフォー マンスを強化している。

ほとんどの研究者は所属する機関を経由してコ ンテンツにアクセスする。DOIの付与は出版社が 統制するプロセスであるので, DOIは出版社が指 定する資料にデフォルトで設定される。機関で働 く利用者にとって, いつでも適切に研究論文の出 版社オンラインバージョンに案内されるとは限ら ない。例えば, 機関は電子ジャーナルを直接購読 していないかもしれず,もしくは機関がアグリゲー トされているデータベースや冊子体の所蔵資料経 由で利用者が見たい記事へのアクセスを提供して いる場合もある。加えて, 図書館は, 出版社Webサ イトで利用できる資料だけを対象とするのではな く, 別のサイトの資料まで案内すべく一連のナビ ゲーションオプションを提供したいと考えるかも しれない。

情報プロバイダは, 図書館のリンキングシステ ムと最適な統合ができるようOpenURLを実装する ことを図書館から求められている。しかし, OpenURLとDOIは競合する技術であるとの䛊った 見解ゆえに, フルテキストへの出版社横断リンク のしくみであるCrossRef/ DOIシステムを利用する 
一次出版社および二次出版社に関するある種の混 乱を招いたのであった。両者は決して，競合する 技術ではないのである。

OpenURLはコンテキストに依存するリンク付け を目的として, 出版物を記載するメタデータおよ び識別子 (identifier) を転送するメカニズムである (OpenURLの詳細はhttp:/library.caltech.edu/openurl を参照)。リンクリゾルバは機関という状況でリン クを張るシステムで, 入ってくるOpenURLを解釈 し, その機関のローカルな所蔵資料やアクセス権 を考慮し，適切な資料へのリンクを表示する機能 を持つ。リンクリゾルバの機能ゆえに図書館は， 図書館にあわせて設計した一連のリンクやサービ スを提供できる。例えば, フルテキストへのリン ク, 冊子体所蔵資料の所蔵状況をチェックするた めの自館の目録データへのリンク, ドキュメント デリバリ（文献コピーの提供）もしくはILLサービ スへのリンク, データベースや検索エンジン等へ のリンクなどである。

DOIとOpenURLはいくつかの方法で共同する。ま ず, DOIダイレクトリであるが, このダイレクトリ ではCrossRefのプラットフォームのどこでもリン クリゾルーションを実行できるが，このダイレク トリはOpenURL刘応となっている。つまり, ロー カルリゾルバにアクセスする利用者をダイレクト リで認識できる。利用者がDOIをクリックすると， CrossRefシステムはそのDOIを利用者のローカルリ ゾルバへ向け直して戻す。そして, CrossRefデータ ベースからメタデータを検索して引き出すための キーとして, そのDOIを使用できる。このメタデー タは論文記事レベルのOpenURLリンクを作る時に 必要である。結果的にDOIをクリックする機関の 利用者は適切な情報資源に導かれるのである。

出版社はそのコンテンツ識別のためにCrossRef DOIシステムを利用すると, それらの出版製品は OpenURLにも適用できるようになる。DOIは出版 社にとってリンキングやデータ管理のプロセスを 容易にするので, 出版社の多くはその出版社が出 す出版物のフルテキストへの第一のリンキングメ カニズムとして, DOIを使用することを要求し出 した。リンクリゾルバはDOIがすでに情報源資料 （引用している文献）に利用されていない場合， CrossRefシステムを使ってDOIを検索することがで きる。

URLは持続性のあるリンキングメカニズムでは ない。もしURLがリンクとして公表されており, そ のURLが示すコンテンツがすでに見られなくなっ
ているならば, そのリンクはもはや機能していな いことを示す。DOIはこの問題を取り上げている もので, DOIを含むOpenURLリンクは同様に持続 性がある。DOIのないOpenURLは, 該当するメタ データがその機関のリンクリゾルバ内で更新され ている場合に限り, 持続性をもって機能するので ある。このプロセスはCrossRefシステムへのアク セス経由であれば大いに能率的である。というの も, CrossRefは多様なメタデータベースのリンク 体系を追跡する必要はなく, 複数の出版社への信 頼の高いリンクを行える単一の情報源を提供する からである。つまり, リゾルバは, 出版社が指定 する情報資源へのリンク付けを適切にしてありさ えすれば, DOIを使って必要なメタデータを確実 に得られる方法なのである。図2 はOpenURL と CrossRefの統合をまとめたものである。

ロスアラモス国立研究所 (Los Alamos National Laboratory) 技術・プロジェクト・リーダーのMiriam Blakeは次のように述べる。「CrossRefはリンキン グ・インフラストラクチュアの肝要な部分である。 DOIだけでは完全な解決策を提供できない。例え ば，DOIは適切コピーへのアクセス課題を解決で きない。CrossRefは, 図書館にとっては実に重大な ステップである, ローカルリゾルーションを扱う のに必要な付加的な情報を提供する。利用者はど れだけ多くのベンダー／出版社が論文記事を提供 できるかなどには関心がない。利用者はリンクの 中で用意されている論文記事に直接行きたいだけ なのである。さらに, CrossRefを使えばSFXのよう なローカルリゾルーションサーバは, フルテキス トへのリンクだけでなく, さらに広げたサービス を提供するために, メタデータを使ってOpenURL リンクを設定するなりDOIリンクを増大できる。 これは “新世代”の発見ツールの重大な一歩であ る」。(私信)

\section{(3) 仲介業者による適用}

CrossRefは出版社のメンバーに, データベース 出版社, アグリゲータ, ベンダー, その他仲介業 者に提供する標準書誌メタデータの一部としてDOI を自由に流通させるよう奨励している。こういっ た仲介業者は一次出版社が直接提供するDOIを現 在含んでいないレコードのDOIを識別し, 入手し, 得るひとつの方法を求めて直接CrossRefにかかわつ ていくこともある。

CrossRefに参加する仲介業者は現在, 36を数え るにこれらはCrossRefの “affiliate”とも呼ばれるこ 
Open URLリンクはCross Ref を補完する

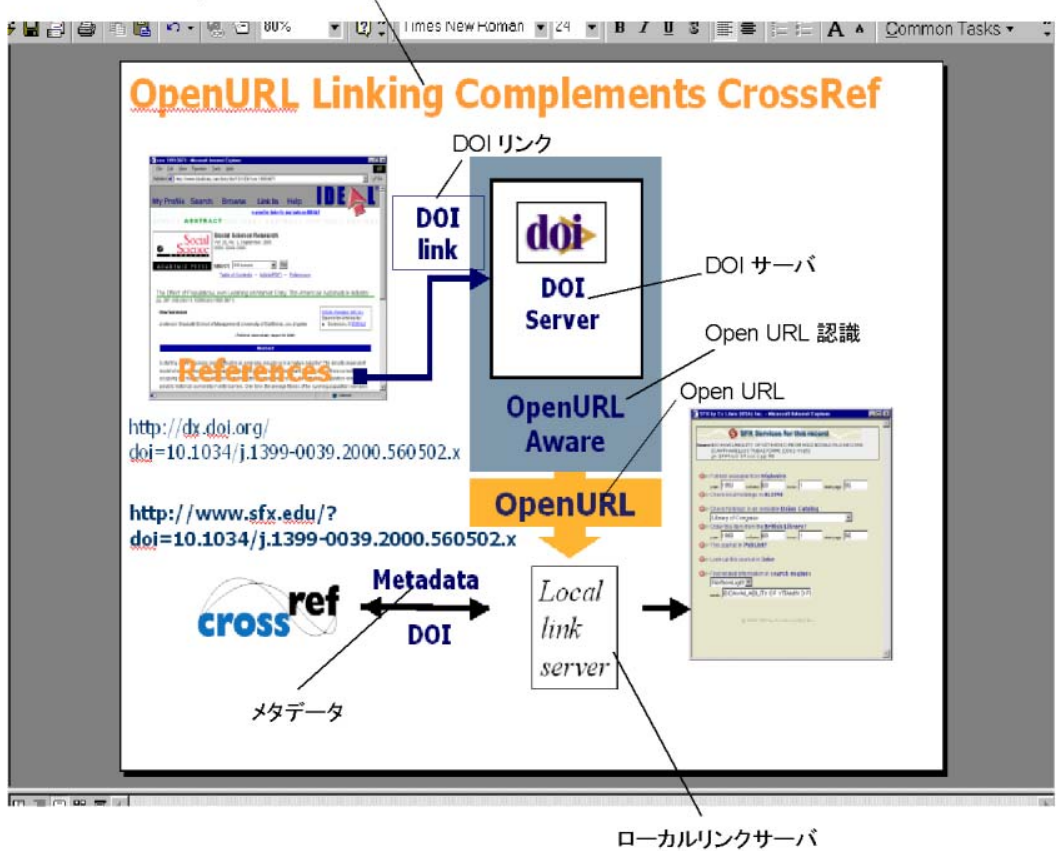

図2 CrossRefとOpenURL統合（Jenny Walkerからの許可を得て複製）

とがある）が, 大手の電子ジャーナル・ホスティ ング・プラットフォームやローカル化リンキング のための図書館ソフトウエア業者も含まれる。一 次出版社と同様，仲介業者はCrossRefに加われば, すべてのCrossRef会員の出版社にリンクできるが, この場合, 仲介業者は2機関間の契約を結ぶ必要も なく, また出版社のそれぞれのリンク体系を追跡 する必要もない。そしてCrossRef以外のリンク関 係を認めていない一次出版社のフルテキストコン テンツにも一部のリンクを顧客に提供する。集中 的なリンキング協定の効率性とフルテキスト資料 に確実にリンクするインデックスの有用性強化に 加えて, 仲介業者によっては, そのジャーナル • ホスティング・サービスの一部としてC CrossRefの 実施を提供するものもあり，またCrossRefシステ ムへ仲介業者が所有するソフトウエアを統合する ものもいる。

抄録／索引データベースを出版するNational Center for Post-Traumatic Stress Disorderの情報専門 家Fred Lernerは次のように述べる。「CrossRefに参 加しているメンバーである我々は,わがPILOTSデー タベースの利用者に, 大規模データベースが提供 するフルテキストへのアクセスと同様のアクセス を提供できる。我々は利用者が要求する便利さと, 利用者が必要とする詳細な索引を提供する。そし
て我々は精神的外傷の研究者や臨床家にとって絶 対に必要な助力者としての役割を維持することが できる。我々はCrossRefなしにはこの種の信頼し うるリンキング機能を提供することは絶対にでき ない」。(私信）

\section{(4) 研究者にとっての利益}

引用文献リンキングは，オンライン上での文献 リサーチの効率をかなり強化するが, そのリンキ ングが出版社によって制限されるなら，それは強 化とはいえない。オンラインで文献をリサーチす る者にとって, 誰がいつ書いたということだけが 重要で, それに対して出版社のアイデンティティ とかジャーナルのアイデンティティなどはほとん どの場合, 出版物の重要な特質にはならないから である。事実ジャーナルや出版社のアイデンティ ティといった, コンテンツを仕分ける仕組みはオ ンライン環境では発見やアクセスの障壁となるこ とが多々ある。引用文献リンキングは，出版物や 出版社をまたいで機能するなら, そして真に総合 的であるなら,そこで初めて有用といえるのである。

フルテキスト引用文献リンキングがなければ, 資料を読んでいる最中に読みたい文献に行き着い ても, それの所在をつかむには別の検索インタ フェースに切り替えなければならない。CrossRef 
を使えばジャーナルや出版社に関係なく，1，2回 クリックするだけで望みの文献に行き着く。参加 機関リンクサーバを持つ利用者は, 適切なリンク を同様に確実に見ることができる。出版社が CrossRefリンキングシステムのコストを負担する ので, DOIリンクをクリックしても料金は請求さ れない。研究者が著者でもある場合は, リンキン グはさらなる注目を集める手段として見なすこと ができる。発信型（アウトバウンド）ハイパーリ ンクを含むことはオンライン出版物に有益な機能 性を加え, 受信型（インバウンド）リンキングは 読者数や引用文献数を増加させることにもなる。

当初,CrossRefリンキングインフラストラクチュ アはエンドユーザには見えないようにと意図され た。CrossRef対応といった, リンクの強制的なブラ ンド付けはなく, 利用者はレファレンスリンクを クリックしても通常, DOIに気づくことはない。し かし, 利用者は今や増大する一連のコンテキスト の中で目に見えるDOI に遭遇している。多くの CrossRef会員は今や, オンライン出版物はもとよ り印刷体の参考文献の中で, 書誌メタデータの基 本的構成項目としてDOIを含める。これは特に才 ンライン版で重要である。例えば，印刷に先んじ て発表される論文記事の場合, 巻号やページ番号 が未定であると, 下記のような記載で, DOIがつく ので，そのまま引用に使用できる。

Kubota, M. et al. J. Geophys. Res. doi:10.1029/ 2002GL016652 (2003).

このように, コンテンツ識別とリンキングのた めのDOIの利用は拡大しており, したがってDOIに 対する利用者の認識も拡大している。CrossRefは 毎週，研究者からどうしたらCrossRefシステムに アクセスできるか, 数多く問い合わせを受けてい る。研究者は自由にアクセスできるマニュアルDOI ルックアップッールとDOIリゾルバボックスにア クセスできる。CrossRefは現在, 公開DOIルックアッ プ・インタフェース上で毎日数千ものマニュアル 質問を受けている。これらの質問のある部分はお そらく資料発見ツールとしてこの公開インタフェー スを利用している研究者からのものである。最後 に, DOIは今や正式に論文の見出し情報や参考文 献中に含まれるので, Googleのような検索エンジ ンでもピックアップされる。DOIはこのように, 特 定のドキュメントを検索するのはもちろん, それ ら資料の参考文献を検索するための便利なキーと なっている。

\section{6. リンキングの強化}

CrossRefネットワークは現在, コンテンツのカ バー範囲 (異なるジャンルやさまざまなレベルへ) という観点からだけでなく機能性という観点にお いても拡大しつつある。近い将来見られる主な進 展のいくつかを以下に述べる。

“Forward linking”とは, 他のどの出版物が特定 の出版物を引用しているかを, 追跡することを指 す。CrossRefを使用して参考文献から外に向けて 出るリンクを設定する。そして, CrossRef会員の出 版社は今や “citied-by” リンク（その出版社のコン テンツを引用している論文記事へのリンク）を検 索できる。この新しいインターネットサービスは オプショナルッールとして提供され, CrossRef会 員はこれを利用して, 自分たちが出版する一次コ ンテンツ中で “citied-by” リンクを表示することが できる。

“Forward Linking” は, CrossRefリンキングネッ トワークの当然の拡張であり, 研究者や学者のた めにより良いオンライン読書環境を提供するであ ろう。John Wiley \& Sons, アメリカ物理学会 (American Physical Society) , Blackwell Publishing, Annual Reviews, Institute of Physics Publishing, American Geophysical Unionなどいくつかの出版社 はこれに参加し, 2004年後半に新しいサービスの 実施を完了すると述べた。

同様な機能の一部として, CrossRef は新規に Forward-Match機能を提供する。これは本来, 合致 (マッチ) するのにその結果を戻さない, そういっ た引用文献に関する問い合わせを利用者が繰り返 しCrossRefに出す手間をなくすためのものである。 質問に警告マークが付くと, 関連するコンテンツ がいったんCrossRefに登録されれば，そのマッチ した結果を記したメールがCrossRefシステムから 自動的に送られる。“Forward Linking” と "Forward Matching” は, CrossRefの科学および学術リンキン グネットワークにとって重要な向上項目である。 これらの進展によって, CrossRefに参加する出版 社はフル引用文献チェーンと真にダイナミックな 引用文献リンクにアクセスでき, 研究者が研究文 献をオンラインでナビゲートするにつれてシステ ム間の境界線を越えられるのである。

“パラメータの受け渡し”は, DOIと同時にキー もしくはコード化されたテキストを送ることを指 す。DOIは, 単に利用者を出版社サイトのURLに導 く記号列であるため, 対象になった出版社は利用 
者がどこから来ているのか, どのようなアクセス 条件が与えられるべきかほとんどわからない。パ ラメータの受け渡しは, 出版社とエンドユーザ (利 用者）の双方に利益を与える追加的機能を有効に するものである。パラメータは引用する機関に関 する情報でもある。この場合, リンクを受け取る 出版社は利用者が出発点とした文献のタイトルと 出版社を知ることになる。そして出版社は利用者 が自らの出版社に行き着くまでのリンクを追跡で きる。そして, どういう出版物が自らの出版社に リンクしているかを知るのである。パラメータの 受け渡しは, またエンドューザの経験にもインパ クトをもたらそう。というのもパラメータの受け 渡しによって, 商標のついたレスポンスページ, リターンボタン(オリジナルサイトに戻るリンク), カスタマイズされたメッセージ送付, エラー処理, 特定のサイトから入ってきた利用者が即座にフル テキストへアクセスできる，といった特別な取引 ルールが可能になるからである。

“Multiple resolution”は，DOIをそれぞれに持つ 複数のエレメントを集合させることを意味する。 したがって, 利用者は 1 回リンクすると, 該当する 出版社が提供するオプションメニュー表示を目に することになる。このオプションとは例えば，同 じコンテンツ, もしくはひとつの作品を別の物理 的に表示させたものの代替物サイトにアクセスす
るオプション, 関連資料を見るオプション, 出版 物の中で情報をまとめたり, 掘り下げたりするオ プション, 関連するメタデータにアクセスするオ プション, 著者に関する詳細情報を得るための才 プション, コンテンツの権利を購入・八手するオ プションなどである。図3はCrossRefのWebサイト 上の “Multiple resolution”デモを示す。

“CrossRef Search”は2004年4月に始まった出版社 横断検索のプロトタイプである。

このパイロットプログラムは, 広範囲な学術研 究を対象とする主要 9 出版社が発行しているジャー ナルや会議録論文のフルテキストをインデックス し, 検索することを可能にする。これまではフル テキスト検索を試みる利用者は $2 つ の$ 不満足なオプ ション, すなわち 1 つ出版社サイトを検索する か, あるいはWeb経由で該当しそうな検索の網を すべてに張るか，のオプションに直面していた。 “CrossRef Search” はおなじみのGoogle技術を使い, フルテキストへのターゲット検索, 学際的分野検 索, そして出版社を横断するフルテキスト検索を 提供する。

“CrossRef Search”イニシアチブは, 研究界と図 書館界に代わって出版社間の障壁を壊すという CrossRefの使命の当然の拡張である。あれやこれ やのツールを使い, CrossRefとその会員はオンラ イン検索経験を改善する諸方法を探し続ける。

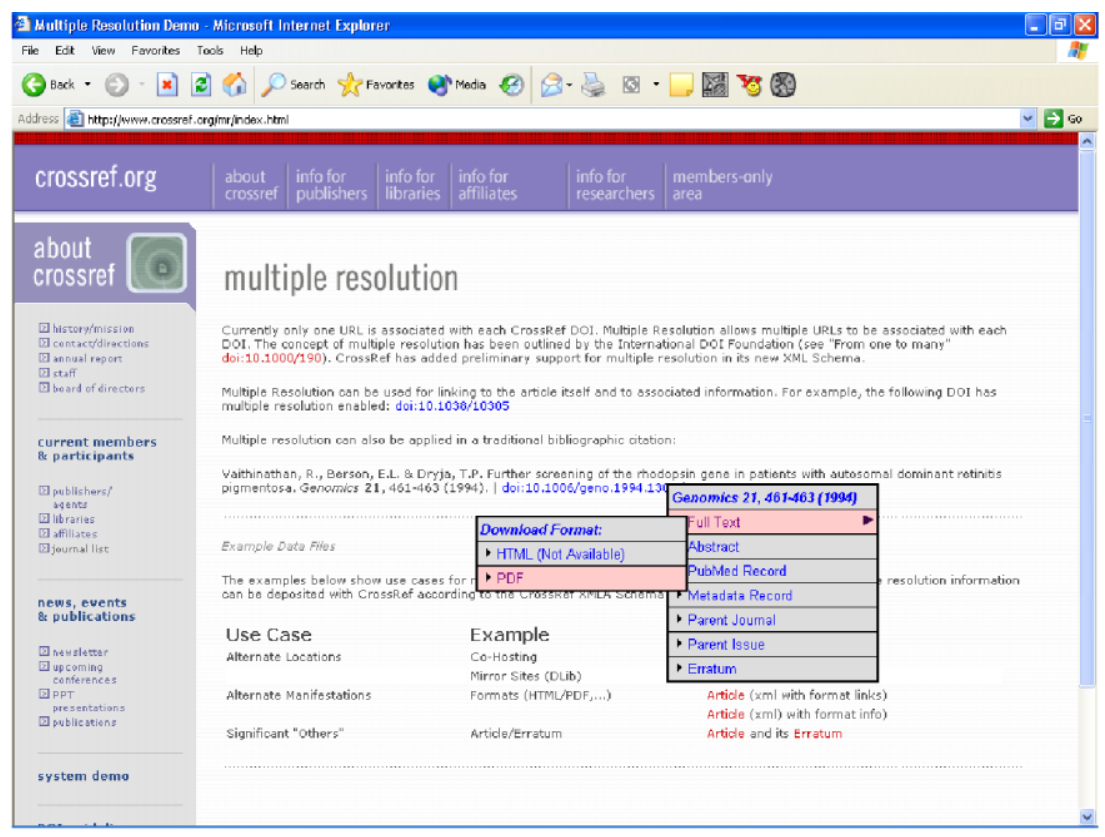

図3 1つの引用文献からー連のリンキングオプションを提供するMultiple resolution (http://www.crossref.org/mr/index.html) 


\section{7. 包括的リンキングネットワークに 向かって}

オンライン上での文献リサーチに関するコンテ ンツを真に包括的にリンク付けすることは実現可 能である。包括的なリンクを実現するには, 最終 的にはDOIディレクトリは特許,テクニカルレポー 卜, 政府が出す資料, 教材, データ類, 画像など の研究に関する出版物中でリンクされる文献資料 のあらゆるタイプに対する識別子を含むことにな ろう。これには複数のDOI登録機関の協力が関与 してくる。そういった機関の中には世界の異なる 地域, 異なるコンテンツタイプ, そして異なるア プリケーションを対象とする多数の機関が含まれ よう。

コンテンツタイプの局面に加え,リンキングネッ トワークはその他の3つの主要な局面でも拡大し続 けよう。

(1) 出版社や機関が長期保存資料をデジタル化する のにつれ，遡及的に文献をリンクする

(2) DOIがジャーナルタイトルのような高いレベル にだけでなく, それより下位の部分のコンテン ツに割り当てられるにつれ, さまざまなレべル のコンテンツにリンクする

(3)DOIのMultiple resolutionを経由することにより， 利用者はリンクを1回クリックすることで, 出 版社が設計するオプションの表示が見られる。 ローカルリンクリゾルバー, もしくは利用者を
アクセス特典やオプションに結びつける手段が 最終的に備わった世界においては，これらすべ てのDOIは, コンテキストセンシティブな（背 景もしくは利用者が置かれている状況に依存す る）方法で機能しょう（resolve）。

\section{8. おわりに}

CrossRefは進化している。CrossRefは出版社の大 小にかかわらず，同様に利益をもたらし，そのリ ンキングネットワークは, すべての学術·専門分 野を越えて包含し; 図書館は無料で利用でき; OpenURLと統合でき; アクセス・モデルは中立で あり；二次出版社のニーズにより良く適合できる ように条件を調整してきた。つまり, CrossRefは利 用者がオンライでコンテンツを探し歩く作業の際 に経験する摩擦を減らす方法を模索し続ける。 研究者と研究出版社の双方にとって恐らくその 最も重大な恩恵として, CrossRefは, 相互リンクと 容易な文献検索という要求を満たすという点から, 出版社それぞれの出版物のサービスレベルを同じ にそろえるための一助となることであろう。さも なければ，情報プロバイダ間の相互リンクへと向 かう動きに取り残されているかもしれない小規模 出版社を含めることによって, CrossRefは学術資 料にオンラインでアクセスできるネットワークを 拡大する。 